\title{
Evaluation of the efficiency of Trichoderma, Penicillium, and Aspergillus species as biological control agents against four soil-borne fungi of melon and watermelon
}

\author{
Naima Boughalleb-M'Hamdi ${ }^{*}$, Ibtissem Ben Salem and Mahmoud M'Hamdi
}

\begin{abstract}
Various experiments were carried out to promote biological control under semi-arid ecological conditions. In vitro assay, Aspergillus flavus seemed to be the most effective bioagent against Fusarium oxysporum f. sp. niveum and Fusarium solani f. sp. cucurbitae with mycelial inhibition rate above 50\%. Aspergillus flavus, Aspergillus niger, and Aspergillus terreus exhibited an exceptional hyperparasitism against F. oxysporum f. sp. melonis. The mycelial growth of five Macrophomina phaseolina isolates decreased in the presence of Trichoderma harzianum (44.42\%). In greenhouse experiments, both A. flavus and A. fumigatus used preventively of melon inoculated with FOM generated the highest damage reduction rate of top and root dry weights (40-42 and 51-52\%, respectively) and the lowest disease severity index (DSI). A. flavus was also effective in improving the plant development with the highest shoot (SDW) and root (RDW) dry weight values. Penicillium digitatum, Trichoderma harzianum, and Trichoderma viride treated preventively on watermelon and melon plants inoculated with $M$. phaseolina decreased the damage of SDW and RDW and DSI. The development rate revealed the growth improvement potential of $T$. harzianum (watermelon, 15\%) and A. flavus (melon, 12\%). Watermelon plants inoculated with F. solani f. sp. cucurbitae and treated curatively with Trichoderma erinaceum, T. viride, and A. flavus and other inoculated by $F$. oxysporum f. sp. niveum and treated by Trichoderma helicum recorded the highest values of growth parameters, similarly for T. erinaceum on melon plants inoculated by F. solani f. sp. cucurbitae. Among all treatments for plants inoculated by F. oxysporum f. sp. melonis, those three bioagents T. viride, T. erinaceum, and A. flavus revealed efficiency in plant growth. Trichoderma harzianum is the best bioagents against cucurbit soil-borne pathogens. Preventive treatment represents an effective strategy. Dipping roots with bioagent fungi suspension improve a good interaction pathogen antagonist.
\end{abstract}

Keywords: Root pathogens, Biological control activity, Fusarium species, Macrophomina phaseolina, Melon, Watermelon

\section{Introduction}

Fusarium species are worldwide pathogenic fungi of many crop plants. Fusarium oxysporum Schltdl. is one of the most important phytopathogens causing Fusarium wilt disease in more than a hundred species of plants (Boughalleb \& El Mahjoub 2006). The disease management of Fusarium wilt usually consists of soil fumigation, seed treatment, use of disease resistant varieties,

\footnotetext{
* Correspondence: n.boughalleb@laposte.net

Département des Sciences Biologiques et de la Protection des Plantes, Université de Sousse, Institut Supérieur Agronomique de Chott Meriem Institut Superieur Agronomique de Chott Mariem, Sousse 4042, Tunisia
}

and biological control bacteria to reduce infection and disease severity (Zhang et al. 2008). Fusarium root and stem rot are regarded as also one of the most devastating diseases in cucurbits (Pavlou \& Vakalounakis 2005). Due to the persistent nature of these pathogens in soil, subsequent crops of susceptible melon and watermelon cultivars increase pathogen populations. The diseases are best managed with resistant cultivars. However, new virulent populations (physiological races) may develop in specific locations. Biological control of soil-borne pathogens by microorganisms has been considered a good environmentally alternative to the chemical treatment 
methods (Eziashi et al. 2007). Many antagonistic microorganisms have been proved to be active In vitro or in vivo. Trichoderma spp. Pers. (Shabir-U-Rehman, et al. 2013), Aspergillus species Micheli (Suárez-Estrella et al. 2007), and Penicillium spp. Link (De Cal et al. 2009) are the most known among the extensive lists. Trichoderma spp. are the most widely studied biological control agents (BCAs) for root and shoot pathogens (Hajieghrari et al. 2008), applied even in post-harvest (Woo et al. 2014). Gava and Menezes (2012) showed that selected isolates of Trichoderma spp. were efficient to control soil-borne pathogens of melon in field. Several microorganisms have been reported as plant pathogen antagonists, but only a small number were applied on a commercial scale (Fravel 2005).

The use of rhizophere Trichoderma harzianum Rifai, for controlling the spread of Macrophomina phaseolina in agronomical crops, has been suggested (Vasebi et al. 2013). Furthermore, different species of Trichoderma have been found to be effective in protecting the root system for some crops against other types or strains of pathogenic fungi, e.g., Fusarium solani (Mart.) Sacc. and M. phaseolina (Malik \& Dawar 2003). Recently, Khalili et al. (2016) demonstrated that three T. harzianum isolates significantly inhibited the growth of M. phaseolina in vitro and field studies.

The aims of the present study were to evaluate the in vitro potential biological control of Trichoderma spp., Penicillium spp., and Aspergillus spp., against three species of Fusarium, and M. phaseolina, and to confirm their efficiency against the main cucurbit soil-borne pathogens in pot planted with melon and watermelon seedlings.

\section{Material and Methods \\ Pathogen and antagonist strains}

Twenty-two pathogens belonging to genus Fusarium, i.e., $F$. oxysporum f. sp. niveum, $F$. oxysporum f. sp. melonis, $F$. solani f. sp. cucurbitae, and M. phaseolina were used in vitro, and only eight were chosen for in vivo studies. Ten antagonist's isolates were tested: four Trichoderma sp. ( $T$. erinaceum Bissett, C.P. Kubicek \& Szakács (watermelon); $T$. viride Schumach.; T. helicum Bissett, C.P. Kubicek \& Szakács; and T. harzianum (melon)), two Penicillium sp. (P. digitatum (Pers.) Sacc. and P. italicum Wehmer (watermelon)), and four Aspergillus sp. (A. niger (melon), A. flavus Link, A. fumigatus Fresen., and A. terreus Thom (grafted watermelon)). The colonial and microscopic characteristics of the fungal isolates were determined. The pathogen and potential bioagents used in the present research were obtained from the Culture Collection Unit of the Laboratory of Phytopathology (ISA Chott Meriem, Sousse, Tunisia), and they were also isolated from infected cucurbit and tomato plants collected from agricultural fields in Tunisia (Table 1).

\section{In vitro experiment: antagonistic effect}

Two disc plugs (0.5-cm diameter) of pathogen and antagonist (4 days old culture) were transferred respectively to a single potato dextrose agar (PDA) plate $(9-\mathrm{cm}$ diameter). The antagonist plug was placed on the one side of the plate (about $2 \mathrm{~cm}$ from the edge of the plate towards the center), while the pathogen plug was placed at the other side of the plate opposite to the antagonist plug leaving a distance of $5 \mathrm{~cm}$ between the two plugs. A plug of PDA medium was used as control treatment while the pathogen plug was placed at the other side. Three replications (two plates/replicate) for each individual treatment were made, and the plates were incubated at $28 \pm 2{ }^{\circ} \mathrm{C}$ for 5 days. The inhibition percent of the radial growth was evaluated according to the formula of Hmouni et al. (1996): $I(\%)=\left(1-C_{n} / C_{0}\right) \times 100$; where $C_{n}$ is the radial growth of the pathogen in the presence of the antagonist and $C_{0}$ is the radial growth of control colonies.

\section{In vivo experiment: evaluation of antagonist biological control activity}

In vivo experiments were divided into two assays, the first one represented a preventive treatment of watermelon and melon against $F$. oxysporum f. sp. melonis and M. phaseolina root invasion, respectively. This assay was carried out by root-dipping watermelon and melon seedlings (15 days old) into flask containing a conidial suspension of the different antagonists for $30 \mathrm{~min}$ and $24 \mathrm{~h}$ before inoculation. For the curative assay, melon and watermelon seedlings were treated $24 \mathrm{~h}$ after inoculation with the pathogens by watering each plant with the antagonist suspension $(10 \mathrm{ml})$ as mentioned in Table 2. Two cultivars of melon (cvs. Bonta and Anannas d'Amérique) and two of watermelon (cvs. Sirocco and Charleston Gray) were used in this assay. The seeds were sown in nursery seed trays with cells of volume $250 \mathrm{ml}$, with 15 plants per each treatment with 3 replicates $(5$ plants per replicate and treatment). The substrate used in the experiment consisted of a mixture of peat and vermiculite (1:1), which was autoclaved twice at $120{ }^{\circ} \mathrm{C}$. The $2-1$ pots are then placed in a greenhouse for 30 days. Two positive controls were performed (one by inoculating the plants with only the pathogen and the other with the antagonist $(10 \mathrm{ml}))$ and distilled water for the negative control. The experimental design was a randomized complete block design (RCBD), and the entire experiment was repeated twice. For each fungal species, one cucurbit plants randomly have been distributed in each treatment.

\section{Inoculum preparation}

For Fusarium species and bioagent fungi, the isolates were grown on PDA at $25{ }^{\circ} \mathrm{C}$ for 4 days until sporulation, and then, an Erlenmeyer flask containing $50 \mathrm{ml}$ of 
Table 1 Collection of 22 soil-borne pathogens isolates cucurbit plant host, regions, and date sampling. Four Fusarium oxysporum f. sp. niveum isolates, five Fusarium oxysporum f. sp. melonis isolates, eight Fusarium solani f. sp. cucurbitae isolates, and five Macrophomina phaseolina isolates

\begin{tabular}{|c|c|c|c|c|}
\hline Pathogens & Code & Host & Regions & Sampling date \\
\hline \multirow[t]{4}{*}{ Fusarium oxysporum f. sp. niveum } & FON1 & Watermelon & Chebika & $2009 / 2010$ \\
\hline & FON2 & & Jbeniana & $2009 / 2010$ \\
\hline & FON3 & & Hajeb & $2009 / 2010$ \\
\hline & FON4 & & Chott Meriem & 2010 \\
\hline \multirow[t]{5}{*}{ Fusarium oxysporum f. sp. melonis } & FOM 1 & Melon & Monastir & 2011 \\
\hline & FOM 3 & & & 2011 \\
\hline & FOM 4 & & Kairouan sud & 2011 \\
\hline & FOM 6 & & & 2011 \\
\hline & FOM 8 & & Sejnen & 2011 \\
\hline \multirow[t]{8}{*}{ Fusarium solani f. sp. cucurbitae } & $\mathrm{FSC1}$ & Watermelon & Jbeniana & 2010 \\
\hline & $\mathrm{FSC2}$ & & Hajeb & 2010 \\
\hline & $\mathrm{FSC3}$ & & & 2010 \\
\hline & $\mathrm{FSC} 4$ & & Beja & 2010 \\
\hline & FSC5 & & Chebika & 2010 \\
\hline & FSC6 & Squash & Elkef & 2010 \\
\hline & $\mathrm{FSC7}$ & Watermelon & Jbeniana & 2010 \\
\hline & $\mathrm{FSC} 8$ & & Hajeb & 2010 \\
\hline \multirow[t]{5}{*}{ Macrophomina phaseolina } & MP1 & Melon & Chott Meriem & 2011 \\
\hline & MP2 & Grafted watermelon & Chott Meriem & 2011 \\
\hline & MP3 & Watermelon & Chott Meriem & 2011 \\
\hline & MP4 & Tomato & Chott Meriem & 2011 \\
\hline & MP5 & Melon & Chott Meriem & 2011 \\
\hline
\end{tabular}

Table 2 Different treatments applied on watermelon and melon seedlings in vivo biological control assay. Two type of treatments: preventive (application of fungal antagonist before $24 \mathrm{~h}$ of pathogen) and curative (application of fungal antagonist $24 \mathrm{~h}$ after the inoculation)

\begin{tabular}{|c|c|c|c|c|c|c|}
\hline \multirow[t]{3}{*}{ Seedlings } & \multicolumn{6}{|l|}{ Treatments } \\
\hline & \multicolumn{2}{|l|}{ Preventive } & \multicolumn{4}{|l|}{ Curative } \\
\hline & Melon & Watermelon and melon & Melon & & Watermelon & \\
\hline Pathogens & F. o. f. sp. melonis & M. phaseolina & F. s. f. sp. cucurbitae & F. o. f. sp. melonis & F. s. f. sp. cucurbitae & F. o. f. sp. niveum \\
\hline Antagonists & FOM1/FOM6 & MP1/MP2 & FSC2/FSC5 & FOM1/FOM6 & FSC2/FSC5 & FON1/FON2 \\
\hline Aspergillus flavus & + & + & + & + & + & + \\
\hline A. fumigatus & + & + & - & - & - & - \\
\hline A. niger & + & + & - & - & - & - \\
\hline A. terreus & + & - & - & - & - & - \\
\hline Penicillium italicum & + & + & - & - & - & - \\
\hline P. digitatum & + & + & - & - & - & - \\
\hline Trichoderma viride & + & + & + & + & + & + \\
\hline T. harzianum & + & + & - & - & - & - \\
\hline T. helicum & - & - & + & + & + & + \\
\hline T. erinaceum & - & - & + & + & + & + \\
\hline
\end{tabular}

+ done, - not done 
potato dextrose broth (PDB, $20 \mathrm{~g} / \mathrm{l}$ ) was inoculated with four pieces individually. Spore production was induced in an orbital shaker, and the spores were recovered from culture by filtration. A hemocytometer was used to determine the concentration of the spores $\left(10^{6}\right.$ spores $\left./ \mathrm{ml}\right)$. In the case of M. phaseolina, the isolate were grown on PDA. Thus, 20 plates mixed with $2500 \mathrm{~g}$ of autoclaved potting mix and placed in 20 -cm pots.

\section{Evaluation parameters}

At the end of the experiment, the plants were carefully removed from the pots, and the root systems were gently washed in tap water. Each root system was rated for the disease severity index (DSI) according to each pathogen. For $F$. oxysporum, we adopted the scale described by Vakalounakis and Frangkiadakis (1999) $(0=$ no symptoms; 1 = light vascular discoloration in the stem with or without stunting; 2 = vascular discoloration in the stem, stunting, wilting with or without yellowing of cotyledons; and 3 = dead seedlings). For F. solani f. sp. cucurbitae, the DSI was described by Boughalleb et al. (2005) (0: healthy; 1: slight yellowing of leaves with slight rot pivot and lateral roots and crown rot; 2: significant yellowing in leaves with or without wilting, stunting of plants, severe rot at the pivot and lateral roots, significant rot and browning of vessels in the stem; 3: death of the plant). For $M$. phaseolina, the scale used was described by Ravf and Ahmad (1998) (0: symptomless, 1: 1 to $3 \%$ of shoot tissues infected, 2: $10 \%$ of shoot tissues infected, 3: $25 \%$ of shoot tissues infected, $4: 50 \%$ of shoot tissues infected, and 5: more than $75 \%$ of shoot tissues infected). Other variables were measured to estimate the response of the cucurbits, such as the degree of inhibition exhibited by the antagonist: Damage reduction rate $(R(\%))$ was calculated according to the two positive controls. Damage reduction of shoot and root dry weights: $(R(\%)=(($ DWA - DWP $) /$ DWA $) \times 100$, which DWA is the dry weight (shoot and root) of inoculated plants with antagonist and DWP is the dry weight (shoot and root) of inoculated plant with only the pathogen.

The effect of the antagonist alone on the plants was also studied as the development rate of the dry shoot and root weights: $D(\%)=((\mathrm{DWA}-\mathrm{DW}) / \mathrm{DW}) \times 100$, where DWA is the dry weight (shoot and root) of the plants inoculated only by the antagonist and DW is the dry weight (shoot and root) of the healthy plants.

At the end of the curative treatment, agronomic parameters were determined including the shoot and root fresh (SFW and RFW) and dry weights (SDW and RDW) and the plant shoot and root height (SH and $\mathrm{RH}$, respectively).

\section{Statistical analysis}

The data were analyzed by ANOVA using SPSS version 20.0 statistical software (SPSS, SAS Institute, USA) to evaluate parameter values differences. Differences between treatments were determined by Duncan's multiple range test at $5 \%$ of significance level.

\section{Results and discussion}

In vitro experiment: antagonism effect

Data presented in Tables 3 and 4 indicated clearly that there was a significant reduction in mycelia growth after confrontation of tested pathogens with all antagonists. As shown in Table 3, the different species exhibited a significant reduction of mycelium growth of $F$. oxysporum f. sp. niveum which varied from 7.22 (FON2/ Penicillium italicum) to $74.68 \%$ (FON4/Aspergillus fla$v u s)$. This potential antagonist seemed to be the most effective bioagent with inhibition rate above $50 \%$.

A. flavus reduced also the development of all $F$. solani $\mathrm{f}$. sp. cucurbitae isolates and obtained data ranging from 46.25 (FSC8) to $49.6 \%$ (FSC2). However, F. solani f. sp. cucurbitae isolates showed a good resistance against the three Trichoderma species with inhibition rate below $30 \%$. Among the different potential bioagents, Trichoderma erinaceum and Penicillium digitatum succeed to decrease the mycelial growth of $F$. oxysporum f. sp. niveum (41\%) and F. solani f. sp. cucurbitae (32\%) (Table 3).

The results from the dual culture tests are shown in Table 4. It appears that the growth rates of the five isolates of $F$. oxysporum f. sp. melonis differed according to the used antagonists. Three Aspergillus species exhibited growth inhibition and showed hyperparasitism against the colonies of F. oxysporum f. sp. melonis. Evaluation of the inhibition zones surrounding the A. flavus, A. niger, and $A$. terreus revealed an inhibition of $25 \%$, with values comprised between 16.56 (FOM1/A. flavus) and 36.59\% (FOM8/A. flavus) and from 20.54 (FOM1/A. niger) to 30.46\% (FOM6/ A. niger) and 22\% (from 18.81 (FOM3/ A. terreus) to $35.14 \%$ (FOM1/A. terreus), respectively.

For M. phaseolina, the two Trichoderma species were revealed to be effective. In fact, the mycelial growth of the five M. phaseolina isolates decreased in the presence of Trichoderma harzianum with an average of $44.42 \%$ (values recorded between 38.74 and 52.42\%) and Trichoderma viride (values ranged between 33.27 and 42.43\%). $P$. italicum was the most efficient one with values between 31.95 (MP5) and 46.63\% (MP3). However, values increased in the case of direct confrontation of M. phaseolina and the four Aspergillus species (Table 4).

In vitro biological control activity experiment revealed that $A$. flavus seemed to be the most effective bioagent with mycelial inhibition rate above $50 \%$ of $F$. oxysporum $\mathrm{f}$. sp. niveum and it was able to reduce the mycelial growth of all F. solani f. sp. cucurbitae isolates, followed by $T$. erinaceum. The three Aspergillus species (A. flavus, A. niger, and A. terreus) and $T$. harzianum exhibited an important growth inhibition against the colonies of $F$. oxysporum $\mathrm{f}$. sp. melonis. 
Table 3 Effect of direct dual confrontation, of two Penicillium spp. isolates, three Trichoderma spp. isolates, and Aspergillus flavus, on mycelia growth inhibition of four F. oxysporum f. sp. niveum isolates and eight F. solani f. sp. cucurbitae isolates after 5 days of incubation at $28^{\circ} \mathrm{C}$, means of six Petri plates (two plates per replicate)

\begin{tabular}{|c|c|c|c|c|c|c|c|c|}
\hline \multirow[t]{2}{*}{ Pathogens } & \multirow[t]{2}{*}{ Code } & \multicolumn{6}{|c|}{ Mycelial growth inhibition percentage $(\%)^{a}$} & \multirow[b]{2}{*}{$P$ values } \\
\hline & & P. digitatum & P. italicum & T. erinaceum & T. viride & T. helicum & A. flavus & \\
\hline \multirow[t]{4}{*}{ F. oxysporum f. sp. niveum } & FON1 & $40.56 b \mathrm{AB}$ & $28.90 \mathrm{C} A \mathrm{~B}$ & 46.08ab A & 41.29b A & $39.91 \mathrm{~b} \mathrm{~A}$ & $56.73 a A B$ & $>0.05$ \\
\hline & FON2 & $32.10 \mathrm{c} \mathrm{BC}$ & 7.22d D & $34.30 \mathrm{~b} \mathrm{~B}$ & $29.31 \mathrm{C} \mathrm{BC}$ & $31.00 \mathrm{C} A \mathrm{~B}$ & $52.08 \mathrm{a} A B$ & $>0.05$ \\
\hline & FON3 & $32.98 b \mathrm{BC}$ & 28.97b AB & $40.92 b \mathrm{AB}$ & $38.54 \mathrm{~b} \mathrm{~A}$ & $32.23 b \mathrm{AB}$ & 64.71a A & 0.0425 \\
\hline & FON4 & $39.55 b \mathrm{AB}$ & $30.44 \mathrm{~b} \mathrm{~A}$ & 42.66b A & $36.95 b \mathrm{AB}$ & 40.00b A & 74.68a A & 0.0335 \\
\hline \multirow[t]{8}{*}{ F. solani f. sp. cucurbitae } & FSC1 & $27.48 \mathrm{bc} C$ & 21.89 c C & $37.08 \mathrm{~b} A B$ & $30.94 b c$ B & $29.23 b c$ B & 49.26a B & $>0.05$ \\
\hline & FSC2 & 38.02b B & $24.92 \mathrm{C} \mathrm{BC}$ & $25.04 c$ C & $17.08 \mathrm{c} C$ & $19.21 \mathrm{C} \mathrm{B}$ & 49.60a B & $>0.05$ \\
\hline & FSC3 & 44.65a A & $26.19 \mathrm{C} \mathrm{B}$ & $21.83 c$ CD & $26.90 \mathrm{C} \mathrm{BC}$ & $17.44 \mathrm{c} C$ & 48.94a B & $>0.05$ \\
\hline & FSC4 & $39.13 b$ AB & $28.57 c A B$ & 25.57 c C & 14.20 c C & $20.00 \mathrm{cB}$ & $46.25 a \mathrm{~B}$ & $>0.05$ \\
\hline & FSC5 & $28.35 b \mathrm{C}$ & $25.21 \mathrm{~b} \mathrm{~B}$ & $26.13 b \mathrm{C}$ & $31.00 \mathrm{~b} \mathrm{~B}$ & $24.91 b$ B & 48.89a B & $>0.05$ \\
\hline & FSC6 & $24.00 \mathrm{~b} C$ & $24.09 b$ BC & 19.60b CD & $18.57 \mathrm{~b} C$ & 19.84b B & 46.93a B & $>0.05$ \\
\hline & FSC7 & $35.85 b$ B & $24.27 \mathrm{~b} \mathrm{BC}$ & $17.08 \mathrm{bc} D$ & 10.93 c D & $19.28 \mathrm{bc} \mathrm{B}$ & 46.93a B & $>0.05$ \\
\hline & FSC8 & 19.49b D & $17.74 b \mathrm{CD}$ & $24.54 b$ C & $15.34 b \mathrm{C}$ & $22.00 \mathrm{~b} \mathrm{~B}$ & $46.25 a$ B & $>0.05$ \\
\hline$P$ values ${ }^{c}$ & & $>0.05$ & $>0.05$ & $>0.05$ & $>0.05$ & $>0.05$ & $<0.05$ & \\
\hline
\end{tabular}

${ }^{a}$ Mycelial growth inhibition percentage values; means of three replicates (two Petri plates per replicate). Duncan's multiple range test: values followed by different letters are significantly different at $P \leq 0.05$. Capital letters are for comparison of means in the same column. Small letters are for comparison of means in the same row

${ }^{b}$ Duncan's multiple range test is for comparison of means among fungal antagonists with the same pathogen on mycelial growth inhibition

'Duncan's multiple range test is for comparison of means among pathogens in the same fungal antagonist on mycelial growth inhibition

These results are in agreement with many reports. In fact, El-Sheshtawi et al. (2014) demonstrated that the presence of many biological control agents for Fusarium wilt which are able to exhibit high properties to inhibit conidial production over $90 \%$, such as T. harzianum, Penicillium oxalicum Currie \& Thom, and non-pathogenic F. oxysporum. Furthermore, Boughalleb et al. (2008) showed the good effect of three T. harzianum isolates against $F$. oxysporum f. sp. niveum and $F$. solani f. sp. cucurbitae, with a reduction of the colony diameter up to $50 \%$. In the present

Table 4 Effect of direct confrontation of two Penicillium spp. isolates, two Trichoderma spp. isolates, and four Aspergillus sp. isolates on mycelial growth inhibition of F. oxysporum f. sp. melonis and M. phaseolina after 5 days of incubation at $28^{\circ} \mathrm{C}$, means of six Petri plates (two plates per replicate)

\begin{tabular}{|c|c|c|c|c|c|c|c|c|c|c|}
\hline \multirow[t]{2}{*}{ Pathogens } & \multirow[t]{2}{*}{ Code } & \multicolumn{8}{|c|}{ Mycelial growth inhibition percentage $(\%)^{a}$} & \multirow[b]{2}{*}{$P$ value } \\
\hline & & P. digitatum & P. italicum & T. viride & T. harzianum & A. flavus & A. niger & A. fumigatus & A. terreus & \\
\hline \multirow[t]{5}{*}{ F. oxysporum f. sp. melonis } & FOM1 & $19.31 b \mathrm{C}$ & $11.43 c \mathrm{C}$ & $11.61 \mathrm{c} C$ & 16.75b D & $16.56 \mathrm{~b} \mathrm{C}$ & $20.54 b \mathrm{~B}$ & 11.75b D & $35.14 a \mathrm{~A}$ & $>0.05$ \\
\hline & FOM3 & 20.38a B & $19.73 b$ B & $10.24 C D$ & $19.8 \mathrm{~b} \mathrm{~B}$ & $25.95 a A B$ & $21.6 a A B$ & 26.35a A & $18.81 \mathrm{~b} \mathrm{C}$ & $>0.05$ \\
\hline & FOM4 & $17.34 b \mathrm{C}$ & $16.12 b \mathrm{C}$ & 26.43a A & 21.88a BC & 22.1a BC & $24.42 \mathrm{a} A \mathrm{~B}$ & 21.26a BC & $20.6 \mathrm{a} C$ & $>0.05$ \\
\hline & FOM6 & 19.91b B & 23.27a $A B$ & $22.55 a \mathrm{AB}$ & $16.6 \mathrm{~b} C$ & 25.71a $A B$ & $30.46 a \mathrm{~A}$ & $15.19 b \mathrm{C}$ & $24.51 \mathrm{a} A B$ & $>0.05$ \\
\hline & FOM8 & 13.29 c D & $25.6 \mathrm{~b} A B$ & $8.71 d \mathrm{D}$ & $23.31 b \mathrm{C}$ & 36.59a A & $27.86 b \mathrm{bB}$ & 11.07 C D & $12.4 \mathrm{CD}$ & $>0.05$ \\
\hline$P$ value $^{c}$ & & $>0.05$ & $>0.05$ & $>0.05$ & $>0.05$ & $>0.05$ & $>0.05$ & $>0.05$ & $>0.05$ & \\
\hline \multirow[t]{5}{*}{ M. phaseolina } & MP1 & 48.01a A & 36.22a A & 42.43a A & 42.38a A & $23.77 b$ B & $29.33 b$ B & 35.97a A & $21.84 \mathrm{C} B$ & $>0.05$ \\
\hline & MP2 & 38.54a B & 35.39a B & $38.15 a$ B & 52.42a A & 33.51ab B & 29.78a B & 44.81a A & 44.92a A & $>0.05$ \\
\hline & MP3 & 30.51ab A & 46.63a A & 37.90a B & 46.21a A & 42.56a A & $30.63 a$ B & 24.54 C C & $24.64 c$ C & $>0.05$ \\
\hline & MP4 & $27.09 \mathrm{~b} C$ & 43.97a A & 33.27ab B & $38.74 b$ B & 37.34a B & 31.79a B & 20.79 C D & 20.29cd D & $>0.05$ \\
\hline & MP5 & $35.14 a$ B & 31.95ab B & 41.46a A & 42.38a A & $29.79 b$ BC & 27.29ab C & $29.13 b c$ BC & $28.23 b$ BC & $>0.05$ \\
\hline$P$ value $^{c}$ & & $>0.05$ & $>0.05$ & $>0.05$ & $>0.05$ & $>0.05$ & $>0.05$ & $>0.05$ & $>0.05$ & \\
\hline
\end{tabular}

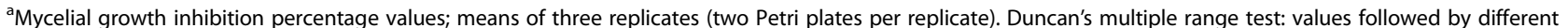
letters are significantly different at $P \leq 0.05$. Capital letters are for comparison of means in the same row. Small letters are for comparison of means in the same column

${ }^{b}$ Duncan's multiple range test is for comparison of means among fungal antagonists with the same pathogen on mycelial growth inhibition

'Duncan's multiple range test is for comparison of means among pathogens in the same fungal antagonist on mycelial growth inhibition 
research, among the tested potential bioagents, $T$. erinaceum and $P$. digitatum revealed to be able to decrease the mycelial growth of these two Fusarium species. In the same sense, Sreevidya and Gopalakrishnan (2016) found that the colony diameter of $F$. solani f. sp. cucurbitae was significantly decreased with Penicillium spp. used at higher concentration (75\%). Dwivedi (2013) confirmed the fungi toxicity of four Aspergillus species (A. niger, A. flavus, A. sulphureus Desm., A. luchuensis Inui), two Trichoderma species (T. viride, T. koningii Oudem.), and two Penicillium species ( $P$. citrinum Thom, $P$. italicum) against $F$. solani. This in vitro assay revealed that pathogenic fungi were significantly decreased even at low concentration of Aspergillus spp. Our findings for the two Trichoderma species against M. phaseolina were confirmed clearly. In fact, $M$. phaseolina mycelial growth decreased significantly in the presence of $T$. harzianum (44.42\%). These results proved those of Khalili et al. (2016).

A microscopic study was conducted in order to determine the effects of some antagonists on the mycelial growth of $F$. oxysporum f. sp. melonis, $F$. oxysporum $\mathrm{f}$. sp. niveum, and M. phaseolina (Fig. 1A, B). Compared to controls, treated Fusarium species mycelium showed strong lysis (Fig. 1B (a, f)), induction of mycelial cords via anastomosis between hyphal filaments (Fig. 1B (b)), mycelium winding (Fig. 1B (c, e)), and early chlamydospore formation (Fig. 1B (d, g)). The antagonistic effect is limited to not only the mycelial growth reduction but also the penetration, progression, colonization, and sporulation of the antagonist such as penetration sites of antagonist (Fig. 1B (i)) and lysis of M. phaseolina cells (Fig. 1B (j)).
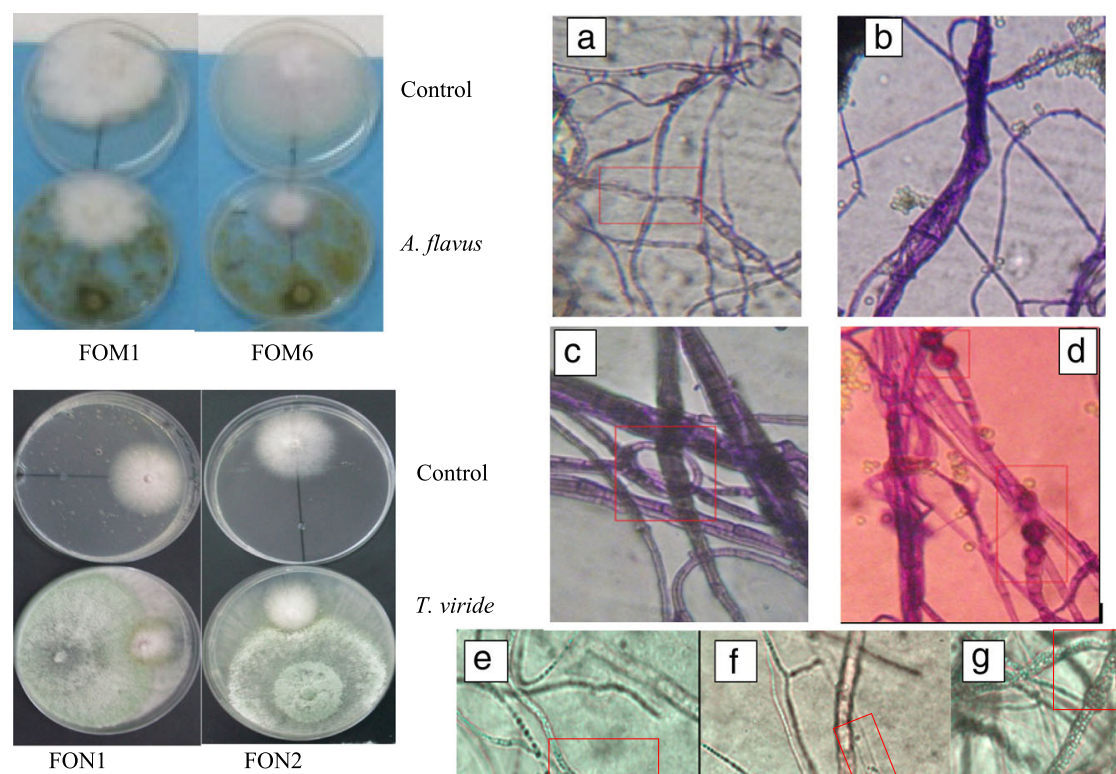

T. viride
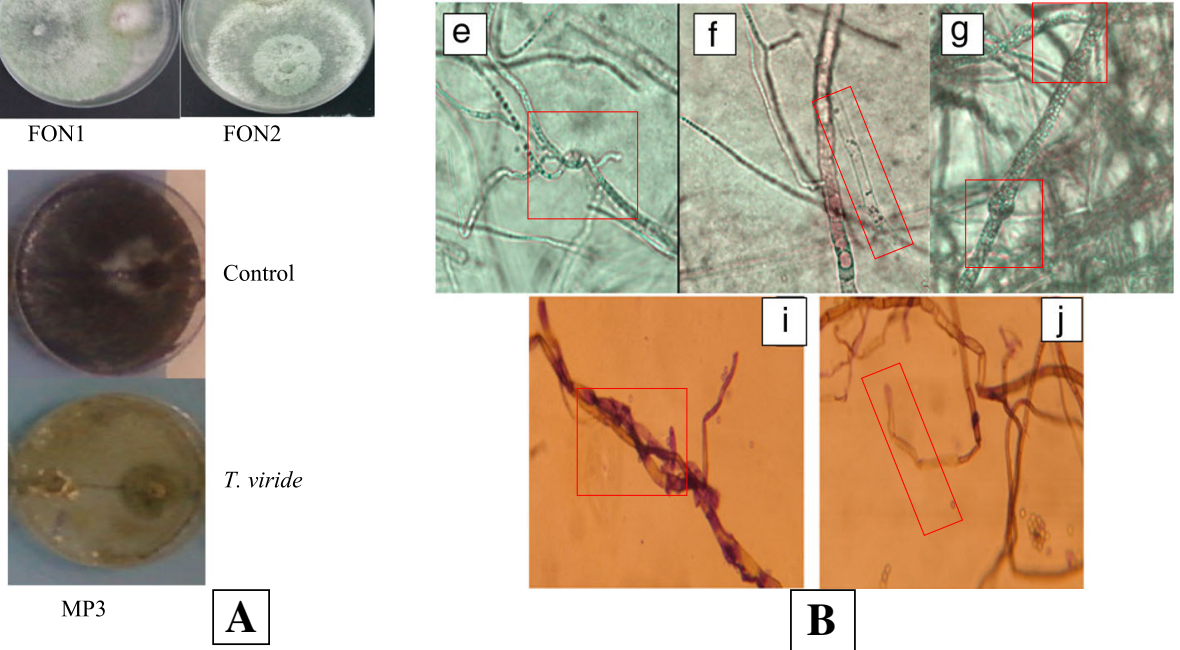

Fig. 1 a Dual confrontation between two F. O. melonis FOM isolates and A. flavus, two F. o. niveum FON isolates and T. viride, and M. phaseolina MP3 and T. viride. b Mycelial interaction in vitro between F. o. melonis FOM $(a, b, c$, and $d)$ and A. flavus, F. o. niveum FON $(e, f$, and $g)$ and $T$. viride, and M. phaseolina MP3 ( $i$ and $j$ ) and T. viride after 5 days of incubation in PDA at $28^{\circ} \mathrm{C}(\mathrm{Gr} \times 40)$ (one plate per treatment was illustrated). Three plates/treatment were taken for microscopic examination of F. O. melonis and F. o. niveum cultures, revealing lysis of fungal mycelia $(a, f)$, mycelia cords $(b)$, mycelium winding $(c, e)$, and chlamydospore formation $(d, g)$. Concerning $M$. phaseolina: $i$ penetration sites of the antagonist and $j$ lysis of the pathogen cells 
Table 5 Damage reduction rate of shoot and root dry weight (\%) and disease severity index values recorded by melon seedlings inoculated with two F. oxysporum f. sp. melonis isolates and treated preventively by four Aspergillus spp. isolates, two Penicillium spp. isolates, and two Trichoderma spp. in vivo assay

\begin{tabular}{|c|c|c|c|c|c|c|}
\hline \multirow[t]{2}{*}{ Antagonists } & \multicolumn{2}{|c|}{ Damage reduction rate of shoot dry weight $\%^{\mathrm{a}}$} & \multicolumn{2}{|c|}{ Damage reduction rate of root dry weight $\%^{\mathrm{a}}$} & \multicolumn{2}{|c|}{ Disease severity index ${ }^{\mathrm{a}}$} \\
\hline & FOM1 & FOM6 & FOM1 & FOM6 & FOM1 & FOM6 \\
\hline A. flavus & $40.61 a^{b}$ & $42.15 a$ & $51.89 a$ & $53.2 \mathrm{a}$ & $0.33 b$ & $0.5 b$ \\
\hline A. fumigatus & $39.89 a$ & $42.25 a$ & $49.63 a$ & $52.55 a$ & $0.5 b$ & $0.67 b$ \\
\hline A. niger & $21.73 b c$ & $18.28 b$ & $34.6 b$ & $21.27 \mathrm{c}$ & $1.67 a$ & $1.83 a$ \\
\hline A. terreus & $36.66 a b$ & $37.75 a$ & $46.86 \mathrm{ab}$ & 42.19ab & $0.83 a b$ & $0.67 \mathrm{~b}$ \\
\hline P. italicum & 27.19abc & $20.49 b$ & $38.04 b$ & $32.53 \mathrm{abc}$ & $1 \mathrm{ab}$ & $1 b$ \\
\hline P. digitatum & $37.81 \mathrm{ab}$ & $32.68 a$ & $47.17 a b$ & $32.53 \mathrm{abc}$ & $0.83 a b$ & $0.67 b$ \\
\hline T. viride & $17.61 \mathrm{c}$ & $12.59 b$ & $23.92 b$ & $23.92 \mathrm{c}$ & $1 \mathrm{ab}$ & 1.33ab \\
\hline T. harzianum & $28.75 a b c$ & $32.97 a$ & $40.87 b$ & 40.46ab & $1 a b$ & $0.5 b$ \\
\hline$P$ value ${ }^{b}$ & $>0.05$ & $>0.05$ & $>0.05$ & $>0.05$ & $>0.05$ & $>0.05$ \\
\hline
\end{tabular}

${ }^{a}$ Damage reduction rate values present the mean of three replicates (5 plants/replicate); $R(\%)=((\mathrm{DWA}-\mathrm{DWP}) / \mathrm{DWA}) \times 100$, where DWA is the dry weight (shoot and root) of inoculated plants with antagonist and DWP is the dry weight (shoot and root) of inoculated plant with only the pathogen and disease severity index scale (Table 3), which present the mean of three replicates (5 plants/replicate)

${ }^{b}$ Duncan's multiple range test: values followed by different letters are significantly different at $P \leq 0.05$

In vitro antagonism by various antagonistic fungi on pathogenic organisms is a field of study in which reports are constantly thronging. High reduction of pathogen growth in vitro tests was observed by all antagonists. In this work, a microscopic observation of the interaction of $F$. oxysporum f. sp. melonis, F. oxysporum f. sp. niveum, and M. phaseolina and some antagonists confirmed the antibiosis such as penetration, progression, colonization, and sporulation. Similar results with other fungi have previously been reported by Benitez et al. (2004).

The possible mechanisms proposed to explain the antagonism were the competition. Therefore, one of the most interesting aspects of biological control is the study of the mechanisms employed by bioagents to reduce soil-borne disease incidence.

\section{In vivo experiment: evaluation of antagonist biological control activity}

The preventive and curative application of antagonist showed a good result with a disease incidence reduction in some agronomic traits in watermelon and melon reaching $50 \%$.

\section{Preventive treatment}

\section{Fusarium oxysporum $f$. sp. melonis}

All tested antagonists for in vitro confrontation with $F$. oxysporum f. sp. melonis (FOM) were used for in vivo experiment. Both A. flavus and A. fumigatus have recorded the highest damage reduction rate of dry shoot and root weights of melon inoculated by FOM1 (41 and 52\%) and FOM6 (42 and 53\%). The in vivo effect of the biological agents were less noted for $T$. viride, and the values were ranged between 17.61 (FOM1) and 12.59\% (FOM6), and 23.92\% (FOM1 and FOM2), respectively.
A. flavus and A. fumigatus significantly decreased the disease severity index (SDI) with values of 0.33 (FOM1) and 0.5 (FOM6) and with 0.5 (FOM1) and 0.67 (FOM6), respectively. The wilt was more apparent on inoculated melon plant treated with A. niger (1.67 (FOM1) and 1.83 (FOM6)) (Table 5). After 1 month of inoculation, the shoot and root dry weights of melon plants treated only with antagonists increased compared to non-treated plants (control). A. flavus induced the best results with an increase of shoot dry weights (11.45\%) and of root dry weights (13\%). T. harzianum (8.36 and 10.08\%) and

Table 6 Beneficial effect of four Aspergillus spp. isolates, two Penicillium spp. isolates, and two Trichoderma spp. isolates on melon plants in vivo assay, revealed by development rate of shoot and root dry weights (\%)

\begin{tabular}{lll}
\hline Antagonists & $\begin{array}{l}\text { Development rate of } \\
\text { shoot dry weight } \%^{\mathrm{a}}\end{array}$ & $\begin{array}{l}\text { Development rate of } \\
\text { root dry weight } \%^{\mathrm{a}}\end{array}$ \\
\hline A. flavus & $11.45 \mathrm{a}^{\mathrm{b}}$ & $12.87 \mathrm{a}$ \\
A. fumigatus & $8.03 \mathrm{abc}$ & $10.16 \mathrm{ab}$ \\
A. niger & $1.72 \mathrm{~d}$ & $4.55 \mathrm{~b}$ \\
A. terreus & $3.24 \mathrm{~cd}$ & $7.5 \mathrm{ab}$ \\
P. italicum & $4.13 \mathrm{bcd}$ & $7 \mathrm{ab}$ \\
P. digitatum & $5.41 \mathrm{bcd}$ & $6.14 \mathrm{ab}$ \\
T. viride & $7.03 \mathrm{abc}$ & $9.26 \mathrm{ab}$ \\
T. harzianum & $8.36 \mathrm{ab}$ & $10.08 \mathrm{ab}$ \\
$P$ value & $>0.05$ & $>0.05$ \\
\hline
\end{tabular}

${ }^{a}$ Development rate presents the mean of three replicates ( 5 plants/replicate); $D(\%)=((D W A-D W) / D W) \times 100$, where DWA is the dry weight (shoot and root) of the plants inoculated only by the antagonist and DW is the dry weight (shoot and root) of the healthy plants

buncan's multiple range test: means followed by different letters are significantly different at $P \leq 0.05$ 
Table 7 Damage reduction rate of top and root dry weight (\%) and disease severity index values recorded by watermelon and melon seedlings inoculated with two M. phaseolina isolates and treated preventively by four Aspergillus spp. isolates, two Penicillium spp. isolates, and two Trichoderma spp. isolates in vivo assay

\begin{tabular}{|c|c|c|c|c|c|c|c|}
\hline \multirow[b]{2}{*}{ Cultivars } & \multirow{2}{*}{$\begin{array}{l}\text { Preventive } \\
\text { treatment }\end{array}$} & \multicolumn{2}{|c|}{ Damage reduction rate of shoot dry weight $\%^{a}$} & \multicolumn{2}{|c|}{ Damage reduction rate of root dry weight $\%^{a}$} & \multicolumn{2}{|c|}{ Disease severity index ${ }^{a}$} \\
\hline & & MP1 & MP2 & MP1 & MP2 & MP1 & MP2 \\
\hline \multirow[t]{7}{*}{ Watermelon } & A. flavus & $14.88 b^{b}$ & $19.39 c$ & $11.73 c$ & $19.40 c$ & $2.33 a$ & $2.67 a$ \\
\hline & A. fumigatus & $8.94 \mathrm{C}$ & $22.19 b$ & $35.09 b$ & $50.18 a$ & $2.33 a$ & $1.83 a b c$ \\
\hline & A. niger & $31.97 a b$ & $27.70 b$ & $15.92 \mathrm{C}$ & $27.70 b$ & $2.33 a$ & $1.50 \mathrm{bc}$ \\
\hline & P. italicum & $13.75 b$ & $20.87 b$ & $26.85 b c$ & $43.00 \mathrm{ab}$ & $2.17 \mathrm{~b}$ & $2.17 a b$ \\
\hline & P. digitatum & $43.36 a b$ & $33.56 b$ & $27.78 \mathrm{bc}$ & $33.57 a b c$ & $1.67 b$ & $1.50 \mathrm{ab}$ \\
\hline & T. viride & $40.42 \mathrm{ab}$ & $44.22 \mathrm{~b}$ & $34.30 b$ & $44.22 a b$ & $1.33 b$ & 1.33abc \\
\hline & T. harzianum & $51.11 a$ & $52.71 a$ & $54.33 a$ & $52.71 \mathrm{a}$ & $1.50 \mathrm{~b}$ & $1.50 c$ \\
\hline$P$ value & & $>0.05$ & $>0.05$ & $>0.05$ & $>0.05$ & $>0.05$ & $>0.05$ \\
\hline \multirow[t]{7}{*}{ Melon } & A. flavus & $3.69 c$ & $14.09 c$ & $18.31 b$ & $16.92 d$ & $1.33 a b$ & $2.00 \mathrm{a}$ \\
\hline & A. fumigatus & $12.64 c$ & $28.40 \mathrm{~b}$ & $30.58 \mathrm{ab}$ & $26.99 \mathrm{~cd}$ & $2.67 a$ & $1.33 a b$ \\
\hline & A. niger & $29.51 a b$ & $35.91 b$ & $26.29 a b$ & $37.35 a b c$ & $1.50 \mathrm{ab}$ & $1.33 a b$ \\
\hline & P. italicum & $7.38 \mathrm{c}$ & $23.44 c$ & $20.25 a b$ & $27.90 \mathrm{~cd}$ & $1.50 a b$ & $1.50 \mathrm{ab}$ \\
\hline & P. digitatum & $34.42 \mathrm{a}$ & $39.51 a$ & $34.06 a$ & 33.30bcd & $1.33 a b$ & $0.83 b$ \\
\hline & T. viride & $30.56 a b$ & $29.09 b$ & $35.41 a$ & $48.18 a b$ & $1.50 a b$ & $1.33 a b$ \\
\hline & T. harzianum & $27.80 \mathrm{~b}$ & $29.52 b$ & $37.23 a$ & $50.68 a$ & $1.33 a b$ & $0.50 \mathrm{~b}$ \\
\hline$P$ value & & $>0.05$ & $>0.05$ & $>0.05$ & $>0.05$ & $>0.05$ & $>0.05$ \\
\hline
\end{tabular}

${ }^{a}$ Damage reduction rate values present the mean of three replicates (5 plants/replicate); $R(\%)=((\mathrm{DWA}-\mathrm{DWP}) / \mathrm{DWA}) \times 100$, where DWA is the dry weight (shoot and root) of inoculated plants with antagonist and DWP is the dry weight (shoot and root) of inoculated plant with only the pathogen and disease severity index scale, which present the mean of three replicates (5 plants/replicate)

${ }^{b}$ Duncan's multiple range test: means followed by different letters are significantly different at $P \leq 0.05$

A. fumigatus (8.03 and $10.16 \%)$ were also effective in improving the plant development (Table 6).

\section{M. phaseolina}

The two Trichoderma species ( $T$. harzianum and T. vir$i d e)$ and $P$. digitatum exhibited the highest damage reduction of shoot and root dry weights $(R(\%))$ for inoculated watermelon plants. The damage reduction rate values were ranged between 51.11 and 40.42\% (MP1) and from 52.71 to $33.56 \%$ (MP2) and varied from 54.33 to $27.78 \%$ (MP1) and between 52.71 and 33.57\% (MP2), for the two parameters, respectively. However, the three Aspergillus species revealed to be less efficient. Watermelon plants treated with A. flavus, A. fumigatus, and A. niger showed symptoms on roots with highest disease severity index (2.33). However, the lowest value was exhibited on plant

Table 8 Beneficial effect of four Aspergillus spp. isolates, two Penicillium spp. isolates, and two Trichoderma spp. isolates, on watermelon and melon plants in vivo assay, revealed by development rate of shoot and root dry weights (\%)

\begin{tabular}{|c|c|c|c|c|}
\hline \multirow[b]{2}{*}{ Antagonists } & \multicolumn{2}{|l|}{ Watermelon } & \multicolumn{2}{|l|}{ Melon } \\
\hline & $\begin{array}{l}\text { Development rate of } \\
\text { shoot dry weight } \%^{\mathrm{a}}\end{array}$ & $\begin{array}{l}\text { Development rate of } \\
\text { root dry weight } \%^{\mathrm{a}}\end{array}$ & $\begin{array}{l}\text { Development rate of } \\
\text { shoot dry weight } \%^{\text {a }}\end{array}$ & $\begin{array}{l}\text { Development rate of } \\
\text { root dry weight } \%^{\mathrm{a}}\end{array}$ \\
\hline A. flavus & $5.98 c^{b}$ & $4.99 b$ & $11.45 \mathrm{a}$ & $12.87 a$ \\
\hline A. fumigatus & $3.02 \mathrm{C}$ & $3.44 b$ & $8.03 a b$ & $10.16 a b$ \\
\hline A. niger & $3.57 c$ & $4.86 \mathrm{~b}$ & $1.72 \mathrm{C}$ & $4.55 b$ \\
\hline P. italicum & $11.41 b$ & $7.76 a b$ & $4.12 b c$ & $7.01 a b$ \\
\hline P. digitatum & 13.93ab & $14.64 a$ & $5.41 b c$ & $6.13 a b$ \\
\hline T. viride & $11.91 \mathrm{ab}$ & $10.32 \mathrm{ab}$ & $7.03 a b$ & $9.26 a b$ \\
\hline T. harzianum & $15.12 \mathrm{a}$ & $15.17 a$ & $8.36 a b$ & 10.08ab \\
\hline$P$ value $^{\mathrm{b}}$ & $>0.05$ & $>0.05$ & $>0.05$ & $>0.05$ \\
\hline
\end{tabular}

${ }^{\mathrm{a}}$ Development rate presents the mean of three replicates (5 plants/replicate); $D(\%)=((\mathrm{DWA}-\mathrm{DW}) / \mathrm{DW}) \times 100$, where DWA is the dry weight (shoot and root) of the plants inoculated only by the antagonist and DW is the dry weight (shoot and root) of the healthy plants

${ }^{b}$ Duncan's multiple range test: means followed by different letters are significantly different at $P \leq 0.05$ 
treated with $T$. viride (1.33). Both $P$. digitatum and $T$. viride recorded the highest values of damage reduction of shoot and root dry weights of melon plants. The lowest values of disease severity index was registered on plants treated with $P$. digitatum (0.83 for MP2) and with $T$. harzianum (0.55 for MP2) (Table 7). For watermelon plants, Trichoderma and Penicillium species exhibited the highest development rate $(D(\%))$ ranging from 11.41 to $15.12 \%$ and from 7.76 to $15.17 \%$, for the shoot and the root dry weights, respectively. However, the best behavior of melon plants was observed when they are treated with A. flavus, T. harzianum, and A. fumigatus (Table 8).

\section{Curative treatment}

\section{Watermelon}

The efficiency of the three Trichoderma species and $A$. flavus, applied through plantation, on growth parameters was studied under greenhouse conditions. The results for $F$. solani f. sp. cucurbitae (FSC5) revealed that $T$. harzianum increased significantly the root height $(16.6 \mathrm{~cm})$, root fresh $(0.47 \mathrm{~g})$, and dry weight $(0.23 \mathrm{~g})$. In the same sense, the treatment with A. flavus produced the highest values of shoot height $(49.6 \mathrm{~cm})$ and dry weight $(2.22 \mathrm{~g})$. Watermelon plants inoculated with FSC2 and treated by $T$. viride exhibited a beneficial effect on shoot height $(44.9 \mathrm{~cm})$, fresh weight $(6.14 \mathrm{~g})$, and root dry weight (0.16). Plants inoculated by F. oxysporum f. sp. niveum and treated with the three Trichoderma species showed an improvement of the different growth parameters. The treatment with $T$. helicum generated the highest shoot height $(\mathrm{TH})(61.3 \mathrm{~cm})$ and increased also the shoot fresh weight (SFW) of watermelon plants inoculated with FON2 (12.6 g). T. viride and T. erinaceum improved the root fresh weight and the shoot and root dry weights with values of 0.75 , 2.91, and 0.23 g, respectively (Table 9).

\section{Melon}

The best growth parameters on melon plants inoculated by FSC5 were recorded in the presence of $T$. erinaceum with values of $16.7 \mathrm{~cm}(\mathrm{RH}), 7.31$ (SFW), $0.46 \mathrm{~g}$ (RFW),

Table 9 Comparison of different growth parameter values: shoot and root heights (cm), shoot and root fresh weights (g), and shoot of root dry weights $(\mathrm{g}$ ) recorded by watermelon seedlings inoculated by two F. solani f. sp. cucurbitae isolates (FSC 5 and FSC 2) and two F. oxysporum f. sp. niveum isolates (FON 1 and FON 2) and treated curatively by three Trichoderma spp. isolates and A. flavus

\begin{tabular}{|c|c|c|c|c|c|c|c|}
\hline \multirow[t]{2}{*}{ Pathogens } & \multirow[t]{2}{*}{ Treatments } & \multicolumn{6}{|c|}{ Growth parameters } \\
\hline & & $\overline{\mathrm{SH}(\mathrm{cm})^{\mathrm{a}}}$ & $\mathrm{RH}(\mathrm{cm})^{\mathrm{a}}$ & SFW $(g)^{a}$ & RFW $(g)^{a}$ & $\mathrm{SDW}(\mathrm{g})^{\mathrm{a}}$ & $\overline{R D W}(\mathrm{~g})^{\mathrm{a}}$ \\
\hline \multirow[t]{5}{*}{ FSC5 } & T. erinaceum & 46.80 efgh $^{\mathrm{b}}$ & 16.40abcde & 6.46def & $0.21 \mathrm{ef}$ & 1.55defghi & 0.15 defg \\
\hline & T. viride & 48.70defg & $15.20 \mathrm{cdefg}$ & $6.20 \mathrm{efg}$ & $0.35 \mathrm{cde}$ & 1.44fghij & $0.17 \mathrm{bcdef}$ \\
\hline & T. helicum & 44.00fghij & 16.60abcd & $5.21 \mathrm{fgh}$ & $0.47 \mathrm{bcd}$ & 1.63defgh & $0.23 a b$ \\
\hline & A. flavus & 49.60def & 16.40abcde & $5.04 \mathrm{fgh}$ & $0.27 \mathrm{def}$ & $2.22 b$ & $0.18 \mathrm{abcd}$ \\
\hline & FSC5 & 40.80hij & 13.50fgh & 4.20hi & $0.14 f$ & $1.90 \mathrm{bcd}$ & $0.10 \mathrm{~g}$ \\
\hline \multirow[t]{5}{*}{ FSC2 } & T. erinaceum & $38.60 \mathrm{ij}$ & 14.30defgh & $5.61 \mathrm{fgh}$ & $0.33 \mathrm{cdef}$ & 1.47fghij & $0.16 \mathrm{cdef}$ \\
\hline & T. viride & 44.90efghi & 16.90abc & $6.14 \mathrm{efg}$ & 0.31cdef & 1.38ghij & $0.16 \mathrm{cdef}$ \\
\hline & T. helicum & 41.10hij & 17.90ab & $5.88 \mathrm{fgh}$ & $0.28 \mathrm{def}$ & $1.71 \mathrm{cdefg}$ & 0.14 defg \\
\hline & A. flavus & 45.40efghi & $18.60 a$ & $5.22 \mathrm{fgh}$ & $0.29 \mathrm{def}$ & 1.28hijk & $0.15 \mathrm{defg}$ \\
\hline & FSC2 & $27.50 \mathrm{k}$ & $12.20 \mathrm{~h}$ & $2.91 i$ & $0.18 \mathrm{ef}$ & $0.97 \mathrm{k}$ & $0.10 \mathrm{~g}$ \\
\hline \multirow[t]{5}{*}{ FON1 } & T. erinaceum & 51.70cde & $15.80 \mathrm{bcdef}$ & $8.21 \mathrm{~cd}$ & $0.49 b c$ & $2.91 \mathrm{a}$ & $0.23 a$ \\
\hline & T. viride & $60.70 \mathrm{ab}$ & 16.60abcd & $10.77 \mathrm{~b}$ & $0.75 a$ & $2.05 b c$ & $0.18 \mathrm{bcde}$ \\
\hline & T. helicum & 61.30a & $15.80 \mathrm{bcdef}$ & $8.73 c$ & $0.33 \mathrm{cdef}$ & 1.51 efghi & $0.13 \mathrm{defg}$ \\
\hline & A. flavus & $57.00 \mathrm{abc}$ & 14.00efgh & $10.62 b$ & $0.42 \mathrm{~cd}$ & $2.01 b c$ & 0.13 defg \\
\hline & FON1 & 42.00ghij & $12.10 \mathrm{~h}$ & $5.98 \mathrm{fgh}$ & $0.18 \mathrm{ef}$ & 1.12jk & 0.14 defg \\
\hline \multirow[t]{5}{*}{ FON2 } & T. erinaceum & $54.20 \mathrm{bcd}$ & 16.60abcd & 11.73ab & $0.71 a$ & $1.78 \mathrm{cdef}$ & $0.18 \mathrm{bcde}$ \\
\hline & T. viride & 50.30cdef & 16.40abcde & 11.21ab & $0.65 a b$ & 1.46fghij & $0.21 a b c$ \\
\hline & T. helicum & $54.00 \mathrm{bcd}$ & 16.00bcde & $12.60 \mathrm{a}$ & $0.51 b c$ & $1.86 \mathrm{bcde}$ & $0.16 \mathrm{cdef}$ \\
\hline & A. flavus & 46.10efgh & 13.10gh & 7.91cde & $0.28 \mathrm{def}$ & 1.79cdef & 0.13 defg \\
\hline & FON2 & $27.80 \mathrm{k}$ & $12.40 \mathrm{~h}$ & 4.42ghi & $0.20 \mathrm{ef}$ & $0.99 k$ & $0.12 \mathrm{fg}$ \\
\hline Control & & $37.00 \mathrm{j}$ & $12.60 \mathrm{~h}$ & $5.08 \mathrm{fgh}$ & $0.21 \mathrm{ef}$ & $1.18 \mathrm{ijk}$ & $0.13 \mathrm{defg}$ \\
\hline$P$ value $^{\mathrm{b}}$ & & $>0.05$ & $>0.05$ & $>0.05$ & $>0.05$ & $>0.05$ & $>0.05$ \\
\hline
\end{tabular}

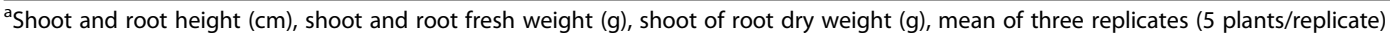

${ }^{b}$ Duncan's multiple range test: means followed by different letters are significantly different at $P \leq 0.05$ 
Table 10 Comparison of different growth parameters values: shoot and root heights $(\mathrm{cm})$, shoot and root fresh weights $(\mathrm{g})$, and shoot of root dry weights (g) recorded by melon seedlings inoculated by two F. solani f. sp. cucurbitae isolates (FSC 5 and FSC 2) and two F. oxysporum f. sp. melonis isolates (FOM) and treated curatively by three Trichoderma spp. isolates and A. flavus

\begin{tabular}{|c|c|c|c|c|c|c|c|}
\hline \multirow[t]{2}{*}{ Pathogens } & \multirow[t]{2}{*}{ Treatments } & \multicolumn{6}{|c|}{ Growth parameters } \\
\hline & & $\mathrm{TH}(\mathrm{cm})^{\mathrm{a}}$ & $\mathrm{RH}(\mathrm{cm})^{\mathrm{a}}$ & $\operatorname{TFW}(g)^{a}$ & RFW $(g)^{a}$ & $\operatorname{TDW}(g)^{a}$ & $\operatorname{RDW}(g)^{a}$ \\
\hline \multirow[t]{5}{*}{ FSC5 } & T. erinaceum & $37.00 a b^{b}$ & $16.70 a$ & $7.31 a$ & $0.46 a$ & $1.36 \mathrm{~b}$ & $0.18 a$ \\
\hline & T. viride & $39.50 a$ & 14.90abc & $6.99 a$ & $0.38 a b$ & $1.34 b$ & $0.12 \mathrm{cdef}$ \\
\hline & T. helicum & $38.00 a$ & 11.20ef & $5.14 b$ & $0.28 \mathrm{bcde}$ & $1.00 \mathrm{c}$ & $0.13 \mathrm{cde}$ \\
\hline & A. flavus & $37.80 a$ & $14.10 \mathrm{bcd}$ & $4.85 b$ & $0.27 \mathrm{bcde}$ & $1.23 b$ & $0.17 a b$ \\
\hline & FSC5 & $15.43 \mathrm{~g}$ & 11.00ef & $3.78 \mathrm{cde}$ & $0.21 \mathrm{de}$ & $0.22 \mathrm{~g}$ & $0.08 \mathrm{fo}$ \\
\hline \multirow[t]{5}{*}{ FSC2 } & T. erinaceum & $32.90 \mathrm{c}$ & $16.70 a$ & $5.26 b$ & $0.34 \mathrm{bc}$ & $1.39 b$ & $0.18 \mathrm{a}$ \\
\hline & T. viride & $31.60 c$ & 15.50ab & $7.36 a$ & $0.34 b c$ & $1.65 \mathrm{a}$ & $0.15 a b c$ \\
\hline & T. helicum & $30.90 \mathrm{~cd}$ & 14.80abc & $5.23 b$ & $0.27 \mathrm{bcde}$ & $1.36 b$ & $0.15 \mathrm{abcd}$ \\
\hline & A. flavus & $33.70 \mathrm{bc}$ & $16.60 a$ & $4.56 b c$ & $0.29 \mathrm{bcd}$ & $1.28 b$ & $0.13 \mathrm{bcd}$ \\
\hline & $\mathrm{FSC2}$ & 24.70ef & 11.00ef & $2.40 f$ & $0.17 e$ & 0.60de & 0.09ef \\
\hline \multirow[t]{5}{*}{ FOM } & T. erinaceum & $22.50 f$ & 15.10ab & 3.37def & 0.23 cde & $0.51 \mathrm{ef}$ & 0.09ef \\
\hline & T. viride & $25.80 \mathrm{ef}$ & 12.90cde & $4.66 \mathrm{bc}$ & $0.24 \mathrm{cde}$ & $0.35 f g$ & $0.12 \mathrm{cdef}$ \\
\hline & T. helicum & $25.00 \mathrm{ef}$ & $13.60 \mathrm{bcd}$ & $5.12 b$ & $0.26 \mathrm{cde}$ & $0.53 \mathrm{ef}$ & $0.13 \mathrm{bcd}$ \\
\hline & A. flavus & $23.00 f$ & 15.30ab & $4.35 \mathrm{bcd}$ & $0.26 \mathrm{bcde}$ & $0.29 \mathrm{~g}$ & $0.11 \mathrm{def}$ \\
\hline & FOM & $15.30 \mathrm{~g}$ & $10.73 f$ & 3.28def & $0.21 \mathrm{de}$ & $0.23 \mathrm{~g}$ & $0.08 f$ \\
\hline Control & & 27.80de & 12.50def & 12.50def & $0.22 \mathrm{de}$ & $0.75 d$ & $0.17 a b$ \\
\hline$P$ value $^{b}$ & & $>0.05$ & $>0.05$ & $>0.05$ & $>0.05$ & $>0.05$ & $>0.05$ \\
\hline
\end{tabular}

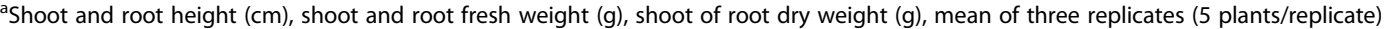

${ }^{\mathrm{b}}$ Duncan's multiple range test: means followed by different letters are significantly different at $P \leq 0.05$

$1.36 \mathrm{~g}$ (SDW), and $0.18 \mathrm{~g}$ (RDW), followed by T. viride treatments for plants inoculated by FSC2. In all the treatments for plants inoculated by $F$. oxysporum f. sp. melonis, significant reduction of disease incidence was noticed compared to control, especially for $T$. viride, $T$. erinaceum, and A. flavus (Table 10).

The present investigation revealed that the highest damage reduction rate of top and root dry weights was recorded on melon inoculated by $F$. oxysporum f. sp. melonis and treated preventively by $A$. flavus and A. fumigatus, also, decreased the disease severity index. A. flavus and T. harzianum were effective in improving the plant development. Among all curative treatments of inoculated melon plants by $F$. oxysporum f. sp. melonis, T. viride, T. erinaceum, and A. flavus were the most effective in reducing the disease incidence of this fungus. This stimulation results in greater axial growth and root mass compared to the control, which is consistent with the work of Mouria et al. (2007) who showed that all strains of $T$. harzianum stimulated the growth of tomato, including vegetative and root biomass. Several reports have previously demonstrated the successful use of biological control agents against Fusarium diseases of various crops. Bernal-Vicente et al. (2009) reported the specific biological control effect of $T$. harzianum against $F$. oxysporum f. sp. melonis under greenhouse nurseries. Watermelon and melon plants treated with $P$. digitatum and T. viride and inoculated with $M$. phaseolina recorded the highest damage reduction of shoot and root dry weights and the lowest disease severity index values. The development rate revealed the growth improvement induced by $T$. harzianum (watermelon, 15\%) and A. flavus (melon, 12\%). In fact, the application of Trichoderma to the soil as biological control agent in the greenhouse or under field conditions not only resulted in reduced disease severity of $M$. phaseolina but also enhanced plant growth (Srivastava et al. 2008). The efficacy of the three Trichoderma species and $A$. flavus, applied curatively of watermelon and melon, on growth parameters was studied under pot culture conditions. Watermelon plants inoculated with $F$. solani f. sp. cucurbitae and treated with T. erinaceum, T. viride, and $A$. flavus showed an improvement of growth parameters. $T$. helicum and A. flavus were effective on plants inoculated by $F$. oxysporum f. sp. niveum. The best growth parameters on melon plants inoculated by $F$. solani f. sp. cucurbitae were obtained in the case of T. erinaceum. Our results supported those of Harman et al. (2004) showing the use of Trichoderma spp. as plant growth enhancers, due to its production of growth hormones and enhanced transfer of minerals to the rhizosphere. The pathogen incidence and disease severity of plant inoculated only with pathogens were higher than the other treatments. Gava and Menezes (2012) revealed that Trichoderma spp. isolates have been 
shown to be efficient colonizers of the melon root system; however, the field efficacy did not exceed 50\%. For M. phaseolina, watermelon and melon plants treated preventively with $P$. digitatum, $T$. harzianum, and $T$. viride recorded the highest values of damage reduction of shoot and root dry weights and the lowest disease severity index. Vasebi et al. (2013) determined the direct interaction between antagonist isolates and $M$. phaseolina involving increased fresh and dry weights of root and foliar parts, which supports my argument. Similar studies have previously shown that antagonists increase seed germination and promote plant growth (Sreedevi et al. 2011). Many studies demonstrated the promising results for Trichoderma species in the biological control of plant diseases applying the mechanisms of competition, antibiosis, and mycoparasitism mediated by hydrolytic enzymes (Munir et al. 2014). Trichoderma-based Trichoderma viride species have been investigated for over 80 years. Numerous researches have been focused on searching and selecting antagonist microorganisms on diverse soil pathogens. Also, synergism between different forms of action modes occurs as the natural condition for the biological control of fungal pathogens. It is widely known that environmental parameters such as abiotic (soil type, soil temperature, soil $\mathrm{pH}$, water potential, and such like) and biotic (plant species and variety, microbial activity of the soil) factors as well as other factors such as method and timing of applications may have influence on the biological control efficacy.

\section{Conclusions}

Dipping watermelon and melon root in antagonists' spore suspensions prior to inoculation of the culture substrate allowed not only the protection of the plants but also the improvement of the agronomic parameters, including better axial growth and greater root biomass. Aspergillus spp. were effective, applied preventively, in reducing $F$. oxysporum f. sp. melonis disease incidence. Furthermore, Trichoderma spp., applied preventively and curatively, showed a significant biological control activities on watermelon and melon plants inoculated with $M$. phaseolina, F. solani f. sp. cucurbitae, and F. oxysporum f. sp. niveum and could be recommended for biological control use. However, although Aspergillus spp. and Penicillium spp. were effective against the tested phytopathogens, fungi are not recommended for biological control assay due to their carcinogenic properties.

\section{Acknowledgements}

This research was supported by UR13AGR03, University of Sousse, Tunisia. The experiments comply with the current laws of the country in which they were performed.

Authors' contributions

All authors read and approved the final manuscript.

\section{Competing interests}

The authors declare that they have no competing interests.

Received: 12 July 2017 Accepted: 6 December 2017

Published online: 15 March 2018

\section{References}

Benitez T, Rincon AM, Limon MC, Codon AC (2004) Biocontrol mechanism of Trichoderma strains. Int Microbiol 7:249-260

Bernal-Vicente A, Ros M, Pascual JA (2009) Increased effectiveness of the Trichoderma harzianum isolate T-78 against Fusarium wilt on melon plants under nursery conditions. J Sci Food Agric 89:827-833

Boughalleb N, Armengol J, El Mahjoub M (2005) Detection of races 1 and 2 of Fusarium solani f. sp. cucurbitae and their distribution in watermelon fields in Tunisia. J Phytopathol 153:162-168

Boughalleb N, El Mahjoub M (2006) Fusarium solani f. sp. cucurbitae and F. oxysporum f. sp. niveum Inoculum densities in Tunisian soils and their effect on watermelon seedlings. Phytoparasitica 34(2):149-158

Boughalleb N, M'hamdi M, Romdhani MS (2008) Etude in vitro de l'activité antagoniste du Trichoderma harzianum vis-à-vis de Fusarium solani f. sp. cucurbitae et de Fusarium oxysporum f. sp. niveum. Revue de l'INAT 23(2):21-36

De Cal A, Sztejnberg A, Sabuquillo P, Melgarejo P (2009) Management Fusarium wilt on melon and watermelon by Penicillium oxalicum. Biol Control 51:480-486

Dwivedi SKE (2013) In vitro efficacy of some fungal antagonists against Fusarium solani and Fusarium oxysporum f. sp. lycopersici causing brinjal and tomato wilt. Int J Biol Pharma Res 4(1):46-52

El-Sheshtawi M, Bahkali AH, Al-Taisan WA, Elgorban AM (2014) Pathogenicity of Fusarium oxysporum f. sp. melonis to melon genotypes (Cucumis melo L.) and its biocontrol. J P A M 8(Spl. Edn. 1):317-324

Eziashi El, Omamor IB, Odigie EE (2007) Antagonism of Trichoderma viridae and effects of extracted water soluble compounds from Trichoderma species and benlate solution on Ceratocystis paradoxa. Afr J Biotechnol 6(4):388-392

Fravel DR (2005) Commercialization and implementation of biocontrol (1). Annu Rev Phytopathol 43:337-359

Gava CAT, Menezes MEL (2012) Efficiency of Trichoderma spp. isolates on the control of soil-borne pathogens yellow melon in field conditions. Rev. Ciênc Agronômica 43:633-640

Hajieghrari B, Torabi-Giglou M, Mohammadi MR, Davari M (2008) Biological potential of some Iranian Trichoderma isolates in the control of soil borne plant pathogenic fungi. Afr J Biotechnol 7(8):967-972

Harman GE, Howell CR, Viterbo A, Chet I, Lorito M (2004) Trichoderma species-opportunistic, avirulent plant symbionts. Nat Rev Microbiol 2:43-56

Hmouni A, Hajlaoui MR, Mlaiki A (1996) Résistance de Botrytis cinerea aux benzimidazoles et aux dicarboximides dans les cultures abritées de tomate en Tunisie. OEPP/EPPO Bull 26:697-705

Khalili E, Javed MA, Huyop F, Rayatpanah S, Jamshidi S, Abdul Wahab R (2016) Evaluation of Trichoderma isolates as potential biological control agent against soybean charcoal rot disease caused by Macrophomina phaseolina. Biotechnol \& Biotechnological Equipment 30(3):479-488

Malik G, Dawar S (2003) Biological control of root infecting fungi with Trichoderma harzianum. Pak J Agric Sci 35:971-975

Mouria B, Ouazzani-Touhami A, Douira A (2007) Effet de diverses souches de Trichoderma sur la croissance d'une culture de tomate en serre et leur aptitude à coloniser les racines et le substrat. Phytoprotection 88(3):103-110

Munir S, Jamal Q, Bano K, Sherwani SK, Abbas MN, Azam S, Kan A, Ali S, Anees M (2014) Trichoderma and biocontrol genes: review. Sci Agric 5:40-45

Pavlou GC, Vakalounakis DJ (2005) Biological control of root and stem rot of greenhouse cucumber caused by Fusarium oxysponum f. sp. radiciscucumerinum by lettuce soil amendments. Crop Prot 24:135-140

Ravf, B.A. and Ahmad, I. 1998. Studies on correlation of seed infection to field incidence of Alternaria alternate and Macrophomina phaseolina in sunflower. 13th Iranian Plant Protection Congress-Karaj. Iran, pp 113

Shabir-U-Rehman WA, Ganie DSA, Bhat JA, Mir GH, Lawrence R, Narayan S, Singh PK (2013) Comparative efficacy of Trichoderma viride and Trichoderma harzianum against Fusarium oxysporum f. sp. ciceris causing wilt of chickpea. Afr J Microbiol Res 7(50):5731-5736

Sreedevi B, Charitha-Devi M, Saigopal DVR (2011) Isolation and screening of effective Trichoderma spp. against the root rot pathogen Macrophomina phaseolina. J Agric Technol 7(3):623-635 
Sreevidya M, Gopalakrishnan S (2016) Penicillium citrinum VFI-51 as bio agent to control charcoal rot of sorghum (Sorghum bicolor (L.) Moench). Afr J Microbiol Res 10(19):669-674

Srivastava JA, Singh RP, Srivastava AK, Saxena AK, Arora DK (2008) Growth promotion and charcoal rot management in chickpea by Trichoderma harzianum. J Plant Prot Res 48(1):81-92

Suárez-Estrella F, Vargas-García MC, López MJ, Capel C, Moreno J (2007) Antagonistic activity of bacteria and fungi from horticultural compost against Fusarium oxysporum f. sp. melonis. Crop Prot 26:46-53

Vakalounakis DJ, Fragkiadakis GA (1999) Genetic diversity of Fusarium oxysporum isolates from cucumber: differentiation by pathogenicity, vegetative compatibility, and RAPD fingerprinting. Phytopathology 89(2):161-168

Vasebi Y, Safaie N, Alizadeh A (2013) Biological control of soybean charcoal root rot disease using bacterial and fungal antagonists in vitro and greenhouse condition. J Crop Prot 2(2):139-150

Woo SL, Ruocco M, Vinale F, Nigro M, Marra R, Lombardi N, Pascale A, Lanzuise S, Manganiello G, Lorito M (2014) Trichoderma-based products and their widespread use in agriculture. Open Mycol J 8:71-126

Zhang T, Shi ZQ, Hu LB, Cheng LG, Wang F (2008) Antifungal compounds from Bacillus subtilis B-FSO6 inhibiting the growth of Aspergillus flavus. World J Microbiol Biotechnol 24:783-788

\section{Submit your manuscript to a SpringerOpen ${ }^{\circ}$ journal and benefit from:}

- Convenient online submission

- Rigorous peer review

- Open access: articles freely available online

- High visibility within the field

- Retaining the copyright to your article

Submit your next manuscript at $>$ springeropen.com 